\title{
Pengembangan Lembar Kerja Siswa Dengan Strategi React Pada Tema "Bermain di Lingkunganku" untuk Siswa Tunagrahita Kelas IV di Home Schooling Primagama Malang
}

\author{
Nuril Nuzulia', Sudirman ${ }^{2}$ \\ 1,2Universitas Islam Negeri Maulana Malik Ibrahim Malang \\ 1nuril.nuzulia@uin-malang.ac.id, 2sudirman.pai@uin-malang.ac.id
}

DOI. $10.18860 / \operatorname{mad} . v 12 \mathrm{i} 2.7538$

Abstract. Development of mentally retarded student worksheets using the strategies of relating, experiencing, applying, cooperating, and transferring (REACT) in Primagama Malang Home Schooling 4th grade is based on the fact that there are no thematic student worksheets for the theme "Playing in My Environment". So far the thematic learning at Primagama Malang Home Schooling is still in general, there are no elements of relating, experiencing, applying, cooperating, and transferring (REACT) in the evaluation of learning, this is evidenced by the developer having never met any thematic student worksheets in which using a strategy relating, experiencing, applying, cooperating, and transferring. The purpose of this study is to produce student worksheets using relating, experiencing, applying, cooperating, and transferring strategies on the theme of "playing in my environment" for mentally disabled students in class IV at Primagama Malang Home Schooling which is valid, practical and effective. The development of this teaching material uses the development of the Dick and Luo Carey design model. The results of this development produce student worksheets based on relating, experiencing, applying, cooperating, and transferring strategies for Grade 4 mentally retarded students at Primagama Malang Home Schooling. The products of the development are tested through several sequential stages namely validation of content experts, validation of learning design experts, validation of learning experts, as well as field trials. The results of the content expert research were $86 \%$ with very good qualifications, $86 \%$ of learning media experts with very good qualifications, $83 \%$ learning experts with good qualifications, $85 \%$ field trials with very good qualifications. Analysis of the data used Paired Samples T Test with SPSS 16 tools and the results of Sig $0,000<0.02$ then Ho is rejected, meaning that there are differences in learning outcomes from classes that have used student worksheets. So, it can be concluded that the use of student worksheets using strategies relating, experiencing, applying, cooperating, and transferring can improve the thematic learning of playing themes in my environment at Primagama Malang Home Schooling.

Keywords. Development; Student Worksheet, REACT Strategy, Tunagrahita

\begin{abstract}
Abstrak. Pengembangan lembar kerja siswa tunagrahita dengan menggunakan strategi relating, experiencing, applying, cooperating, dan transferring (REACT) di Home Schooling Primagama Malang kelas 4 ini didasarkan pada kenyataan belum tersedianya lembar kerja siswa tematik untuk tema "Bermain di Lingkunganku". Sejauh ini pembelajaran tematik di Home Schooling Primagama Malang masih secara umum, tidak terdapat unsur relating, experiencing, applying, cooperating, dan transferring (REACT) didalam evaluasi pembelajarannya, hal ini dibuktikan dengan belum pernah pengembang menemui satupun lembar kerja siswa tematik yang didalamnya menggunakan strategi relating, experiencing, applying, cooperating, dan transferring. Tujuan penelitian ini adalah menghasilkan lembar kerja siswa dengan menggunakan strategi relating, experiencing, applying, cooperating, dan transferring pada tema "bermain di lingkunganku" yang layak untuk siswa tunagrahita kelas IV di Home Schooling Primagama Malang yang valid, praktis dan efektif. Pengembangan bahan ajar ini menggunakan pengembangan model desain Dick and Luo Carey yang terdapat 10 tahap, namun peneliti menggunakan hanya 9 tahap. Hasil pengembangan ini menghasilkan lembar kerja siswa dengan berbasiskan strategi relating, experiencing, applying, cooperating, dan transferring untuk
\end{abstract}




\section{MADRASAH}

Jurnal Pendidikan dan Pembelajaran Dasar

p ISSN: 1979-5599 | e ISSN: 2502-194X

P a g e

kelas 4 tunagrahita di Home Schooling Primagama Malang. Produk dari pengembangan diuji cobakan melalui beberapa tahapan yang berurutan yakni validasi ahli isi, validasi ahli desain pembelajaran, validasi ahli pembelajaran, serta uji coba lapangan. Hasil penelitian ahli isi sebesar $86 \%$ dengan kualifikasi sangat baik, ahli media pembelajaran $86 \%$ dengan kualifikasi sangat baik, ahli pembelajaran $83 \%$ dengan kualifikasi baik, uji coba lapangan $85 \%$ dengan kualifikasi sangat baik. Analisa data yang digunakan Paired Samples T Test dengan alat bantu SPSS 16 dan hasil Sig 0,000 < 0,02 maka Ho di tolak, artinya bahwasannya ada perbedaan hasil belajar dari kelas yang sudah menggunakan lembar kerja siswa. Jadi dapat disimpulkan bahwasannya penggunaaan lembar kerja skswa dengan menggunakan strategi relating, experiencing, applying, cooperating, dan transferring dapat meningkatkan pembelajaran tematik tema bermain di lingkunganku di Home schooling Primagama Malang.

Kata Kunci. Pengembangan; Lembar Kerja Siswa, Strategi REACT, Tunagrahita

Received : 15-08-2019

Approved : 30-01-2020

Revised : 30-01-2020

Published : 27-06-2020

Copyright $($ ) Madrasah Jurnal Pendidikan dan Pembelajaran Dasar. All Right Reserved.

This is an open access article under the CC BY-NC-ND license

(http:/ / creativecommons.org/licenses/by-nc-nd/4.0/).

Correspondence Address: nuril.nuzulia@uin-malang.ac.id

\section{A. PENDAHULUAN}

Pendidikan yang dibutuhkan dimasa saat ini adalah pendidikan yang dapat meningkatkan potensi peserta didik. Pendidikan akan terasa penting saat seseorang masuk ke dalam kehidupan di masyarakat, oleh sebab itu peserta didik diharuskan dapat menerapkan dari yang sudah diperoleh di bangku sekolah guna menghadapi masalah-masalah yang ada di dalam kehidupan sekarang dan di masa depan. Pembelajaran tematik merupakan pembelajaran yang disusun ke dalam bentuk tema dengan melibatkan beberapa mata pelajaran yang disajikan dalam satu wadah secara terpadu. Pembelajaran tematik merupakan model pembelajaran yang dipadukan. Pembelajaran ini menekankan siswa, baik secara individu maupun kelompok untuk aktif menemukan konsep secara holistik, bermakna, serta autentik, sehingga dalam kegiatan pembelajaran siswa akan belajar secara aktif. Pembelajaran tematik sangat efektif dikarenakan mampu menghilangkan serta menolak proses latihan atau hafalan (driil) dan monoton yang merupakan sebagai dasar untuk menanamkan dan membentuk pengetahuan dan struktur intelektual pada anak sekolah dasar secara holistic (Trianto, 2010: 6).

Kurikulum 2013 memiliki target yakni mampu menghasilkan peserta didik yang berkakhlak mulia, berketrampilan, dan berpengetahuan yang berkesinambungan. Materi dan proses pembelajarannya disesuaikan dengan tingkat perkembangan anak. Proses pembelajaran diharapkan mengarah pada student center dan kontekstual dipandu buku tes yang di dalamnya berisi materi dan proses pembelajaran. Guru disini hanya bertugas menjadi motivator dan fasilitator pembelajaran. Kurikulum 2013 ini sangat efektif dikarenakan sesuai dengan teori pendidikan seperti student center active learning, contructivisme theory, democtratic and humanis learning. Konsep ini bukan yang pertama diketahui oleh pendidik, namun konsep yang sangat logis dan sederhana 
hanya akan menjadi teori jika tidak difasilitasi dan di dukung oleh sumberdaya yang memadai, karena di setiap prakteknya akan menimbulkan berbagai macam kendala.

Model pembelajaran inovatif-progresif adalah konsep belajar yang membantu guru dengan mengaitkan materi sesuai dengan dunia nyata peserta didik serta mendorong peserta didik membuat hubungan antara pengetahuan dengan penerapannya sesuai dengan kehidupan sehari-hari baik di kehidupan mereka sebagai anggota keluarga dan masyarakat. Dengan konsep seperti ini, akan membuat pembelajaran lebih bermakna bagi para peserta didik. Dalam kegiatan pembelajaran akan berlangsung dalam bentuk para peserta didik menanya, menalar, mencoba, mengamati, dan mengkomunikasikan sehingga bukan hanya mentransfer pengetahuan dari guru ke siswa saja. strategi dan proses pembelajaran lebih penting dari pada hanya sekedar hasil. Untuk membantu peserta didik memahami konsep dan memudahkan guru dalam pembelajaran maka konsep tersebut diperlukan suatu pendekatan pembelajaran, dimana pendekatan itu mampu mengaitkan materi konteks pelajaran dengan pengalaman nyata dalam kehidupan sehari-hari.

Dalam proses pembelajaran menggunakan pendekatan tematik ini diharapkan anak mampu mengikuti dan memahami proses pembelajaran dengan baik Selain itu salah satu masalah yang dihadapi oleh anak tunagrahita ringan adalah mereka mudah jenuh atau bosan dalam mengikuti proses pembelajaran apa lagi pembelajaran yang kurang disukai oleh anak. Namun dengan menggunakan pembelajaran tematik ini diharapkan anak tidak mudah bosan dalam mengikuti pelajaran. Hal ini karenakan pada pembelajaran tematik proses pembalajaran dilakukan secara terpadu atau dengan kata lain setiap mata pelajaran yang akan diikuti siswa dilakasanakan secara menyatu atau tidak terpisah pisah sehingga dalam waktu yang sama anak mengikuti mata pelajaran yang berbeda beda yang dirangkum dalam satu tema pembelajaran. Selain itu dengan menggunakan pembelajaran tematik ini anak secara tidak sadar mengikuti beberapa mata pelajaran dalam waktu yang sama sehingga pembelajaran lebih bersifat menyenangkan dan tingkat kebosanan siswa bisa diatasi (Nunung, 2010: 3). Hal ini juga didukung karena setiap mata pelajaran yang dipadukan atau ditematikkan dikaitkan antara mata pelajaran yang satu dengan yang lain. Sehingga proses pembelajaran terlihat lebih bervariasi.

Peserta didik tunagrahita sulit berpikir abstrak, sehingga dalam memahami materi tersebut mereka cukup kesulitan jika tidak didukung dengan kegiatan sesuai dengan kehidupan nyata ataupun gambar yang menyertainya (Mumpuniarti, 2007: 21). Oleh sebab itu dibutuhkan alat bantu berupa buku ajar yang memadai. Selanjutnya dengan karakteristik untuk peserta didik tunagrahita, yakni warna tidak terlalu mencolok, garis dan bentuk tidak boleh abstrak. Hal yang paling penting adalah memilih hal-hal yang perlu ditonjolkan. Peserta didik tunagrahita akan mengalami kesulitan jika dihadapkan dengan objek yang kurang jelas tanpa tekanan tertentu.

Pengertian bahan ajar menurut (Depdiknas, 2001: 8) adalah segala bentuk bahan yang digunakan untuk membantu guru dalam melaksanakan kegiatan belajar mengajar. Menurut Depdiknas bahwasannya bahan ajar dikelompokan menjadi 4 kategori, yakni bahan cetak (printed), bahan ajar dengar (audio), bahan ajar pandang dengar (audio visual) dan bahan ajar multimedia interaktif (interactive teaching material). Dalam penelitian ini, kategori yang digunakan adalah bahan cetak berupa lembar kerja siswa (LKS). Rohman dan Amri menyatakan bahwa materi pembelajaran yang menyediakan aktifitas berpusat pada siswa dapat dikemas dalam bentuk LKS. LKS 


\section{MADRASAH}

Jurnal Pendidikan dan Pembelajaran Dasar

p ISSN: 1979-5599 | e ISSN: 2502-194X

P a g e

sebagai bahan ajar bertujuan untuk memudahkan siswa dalam memahami materi yang diberikan (Andi, 2008: 205).

Menurut hasil pengamatan penulis terhadap LKS yang digunakan oleh siswa kelas IV tunagrahita di Homeschooling Primagama Malang dan Home Schooling cabang Primagama Sidoarjo, menunjukkan bahwa LKS yang berbasiskan pembelajaran tematik masih belum tersedia, yang digunakan masih konvensional dengan menggunakan kurikulum KTSP yaitu dimulai dari ringkasan materi, contoh soal kemudian soal. Ringkasan materinya pun tidak dibaca dan dipahami sendiri oleh siswa melainkan dijelaskan oleh guru. LKS tersebut juga tidak menuntun siswa untuk berfikir kritis dan sistematis karena pengertian dan pembahasan tidak diberikan langsung sebelum mengerjakan soal sehingga siswa mengerjkan tanpa tahu pembahasan tersebut

Berdasarkan hasil wawancara yang dilakukan penulis terhadap 4 siswa tunagrahita di Home Schooling Primagama Malang, mereka mengungkapkan bahwa tema bermain di lingkunganku merupakan salah satu tema yang sulit dipahami dan selalu dituntut untuk selalu menghafal. Jika di ambil sampel mata pelajaran materi dalam matematika terdapat materi bangun ruang yaitu kubus dan balok, pada dasarnya kubus dan balok memiliki peluang yang lebih besar untuk dipahami oleh siswa. Hal ini karena banyak benda-benda di sekitar kita yang membuat ide geometri kubus dan balok, misalnya buku tulis, kotak susu, kardus minuman. Namun, ketika siswa belajar dengan menghafal, maka mereka akan langasung mengalami kesulitan, bahan materi pelajaran yang diperoleh belum siap pakai untuk menyelesaikan masalah-masalah dalam kehidupan sehari-hari (Herman, 2008;10). Oleh karena itu, diperlukan inovasi dalam bahan ajar agar siswa tidak hanya pandai dalam melakukan prosedur perhitungan untuk menyelesaikan soal saja, tetapi juga mengerti dan mampu menerapkan konsep pengetahuan yang didapat ke dalam konteks yang lain.

Menurut (Wena, 2010:9) berbagai macam masalah-masalah belajar dan banyaknya strategi pembelajaran, menuntut adanya kemampuan seorang guru agar dapat memadukan antara strategi pembelajaran yang digunakan sesuai dengan karakteristik model belajar siswa. Ada beberapa contoh strategi pembelajaran yang digunakan antara lain strategi dengan pembelajaran siklus, strategi pembelajaran generative dan strategi pembelajaran kontekstual. Bermacam-macam strategi pembelajaran tersebut banyak memiliki karakteristik dan disertai dengan langkahlangkah yang berbeda, dan masing-masing strategi diperuntukkan sesuai dengan permasalahan belajar dan tujuan pembelajaran. Pada penelitian ini, penulis memilih strategi pembelajaran kontekstual. Strategi ini memuat beberapa tahapan-tahapan belajar yaitu Relating, Experiencing, Applying, Cooperating, dan Transferring atau disingkat dengan strategi REACT. Menurut CORD strategi REACT meliputi kegiatan belajar dalam konteks pengalaman hidup seseorang atau pengetahuan yang sudah ada sebelumnya (tahap relating), pembelajaran dilakukan melalui eksplorasi,penemuan, dan penciptaan (tahap experiencing), belajar dengan menempatkan konsp-konsep untuk digunakan (tahap applying), menciptakan komunitas belajar dalam bentuk kerja sama kelompok (tahap cooperating), dan belajar dalam konteks yang baru (tahap transferring).

Berdasarkan penelitian terdahulu yang dilakukan oleh (Agustin dan Kusrini, 2013: 12) bahwa aktivitas siswa selama proses pembelajaran dengan strategi REACT tergolong aktif dan hasil belajar siswa dikatakan tuntas. Dalam penelitian (Rahmawati, 
2013: 15) menyimpulkan bahwa rata-rata hasil belajar siswa dan persentase keaktifan siswa dengan menggunakan pembelajaran strategi REACT lebih tinggi dari siswa dengan pembelajaran ekspositoris. Pemilihan strategi REACT sebagai tahapan belajar yang digunakan dalam penyusunan LKS untuk siswa kelas IV Tunagarhita di Home Schooling Primagama Malang untuk tema "bermain di lingkunganku" karena mampu membantu siswa memahami konsep pada siswa dengan diskusi sebaya, mengaitkan dengan pengetahuan sebelumnya, dan mengerjakan soal-soal latihan. Oeh karena itu, penulis tertarik untuk melakukan penelitian pengembangan dengan judul "Pengembangan Lembar Kerja Siswa Dengan Strategi React Pada Tema "Bermain Di Lingkunganku" Untuk Siswa Tunagrahita Kelas IV Di Home Schooling Primagama Malang".

\section{B. METODE PENELITIAN}

Metode dalam penelitian ini menggunakan metode penelitian dan pengembangan atau Research and Development (RnD). Penelitian pengembangan Research and Development ini merupakan metode penelitian untuk menghasilkan sebuah produk dengan menguji keefektifan produk tersebut (Sugiyono, 2011:297). Penelitian pengembangan ini dirancang dengan menggunakan model pengembangan pembelajaran Walter Dick and Lou Carey. Langkah-langkah prosedural dalam penelitian dan pengembangan yang diklasifikasikan oleh Walter Dick and Carey ini senada dengan uraian Nana Syaodih yakni ada beberapa metode yang digunakan yaitu metode deskriptif, evaluatif, dan eksperimental. Penelitian deskriptif digunakan menghimpun data kondisi produk yang akan dikembangkan, kondisi pengguna, kondisi faktor pendukung dan penghambat pengembangan dan penggunaan produk. Metode evaluasi digunakan untuk mengevaluasi proses uji coba pengembangan suatu produk. produk akan dikembangkan melalui serangkaian uji coba dan setiap uji coba akan di evaluasi. Metode eksperimen digunakan untuk menguji keefektifan dari produk yang dihasilkan.

\section{HASIL DAN PEMBAHASAN}

Pengembang menyusun lembar kerja siswa tunagrahita dengan menggunakan strategi REACT Home Schooling Primagama Malang Kelas 4 dapat meningkatkan hasil belajar. Untuk itu, lembar kerja siswa tunagrahita dengan menggunakan strategi REACT di validasi oleh ahli isi, ahli desain pembelajaran, dan ahli pembelajaran sebelum di uji cobakan di lapangan. Berikut ini akan disajikan gambar hasil jawaban yang diberikan dari ahli isi. Data pada tersebut dapat dibuat gambaran sebagai jawaban dari ahli isi.

Gambar C.1

Hasil Penilaian Ahli Isi

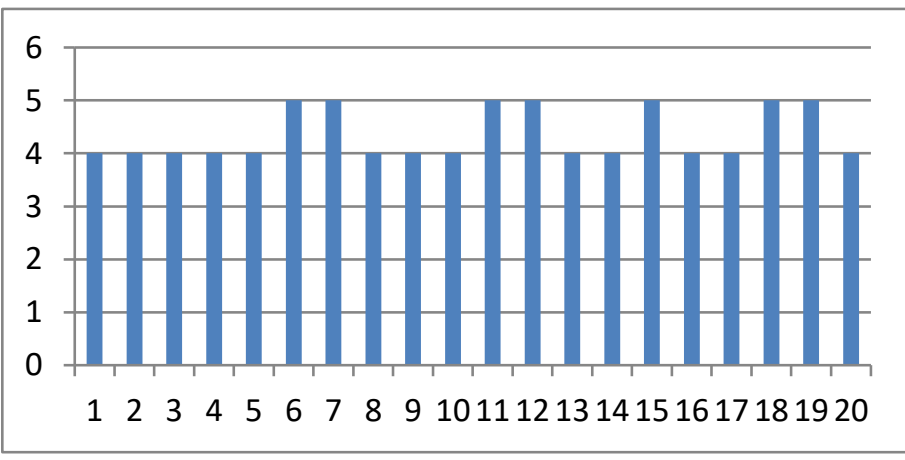

Vol. 12 No. 2 Juni 2020

Madrasah homepage: http://ejournal.uin-malang.ac.id/index.php/madrasah/index 


\section{MADRASAH}

Jurnal Pendidikan dan Pembelajaran Dasar

Berdasarkan hasil penilaian ahli isi terhadap lembar kerja siswa tunagrahita dengan menggunan strategi REACT di Home Schooling Primagama Malang sebagaimana dicantumkan dalam (lamp. 1), maka dapat dihitung prosentase tingkat pencapaian lembar kerja siswa sebagai berikut:

$$
\begin{aligned}
& \text { Prosentase }=\sum \frac{(\text { Jawaban } \times \text { Bobot tiap pilihan })}{n \times \text { Bobot tertinggi }} \times 100 \% \\
& \text { persentase }=\frac{86 \times 1}{20 \times 5} \times 100 \%=\frac{86}{100} \times 100 \%=86 \%
\end{aligned}
$$

Berikut ini akan disajikan gambar hasil jawaban yang diberikan dari ahli desain pembelajaran. Dan data tersebut dapat dibuat gambaran sebagai jawaban dari ahli desain pembelajaran.

Gambar C.2

Hasil Penilaian Ahli Desain Pembelajaran

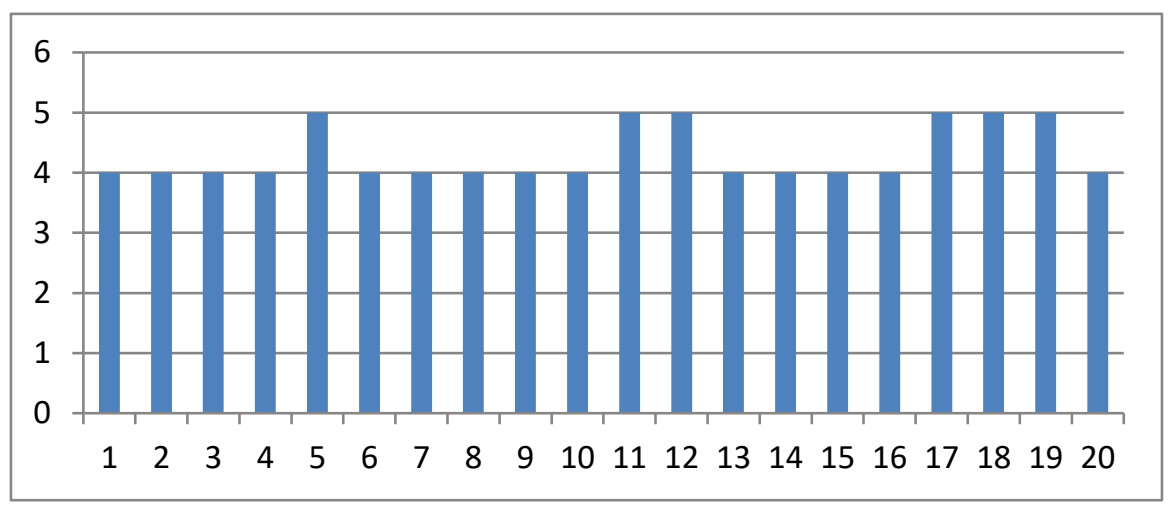

Berdasarkan hasil penilaian ahli desain pembelajaran terhadap lembar kerja siswa tunagrahita dengan menggunan strategi REACT di Home Schooling Primagama Malang sebagaimana dicantumkan, maka dapat dihitung prosentase tingkat pencapaian lembar kerja siswa sebagai berikut:

$$
\begin{aligned}
& \text { Prosentase }=\sum \frac{\text { (Jawaban } \times \text { Bobot tiap pilihan })}{n \times \text { Bobot tertinggi }} \times 100 \% \\
& \text { persentase }=\underline{86 \times 1} \times 100 \%=\underline{86} \times 100 \%=86 \%
\end{aligned}
$$

$$
20 \times 5 \quad 100
$$

Berikut ini akan disajikan gambar hasil jawaban yang diberikan dari ahli pembelajaran. Dan data tersebut dapat dibuat gambaran sebagai jawaban dari ahli pembelajaran. 
Gambar C.3

Hasil Penilaian Ahli Pembelajaran

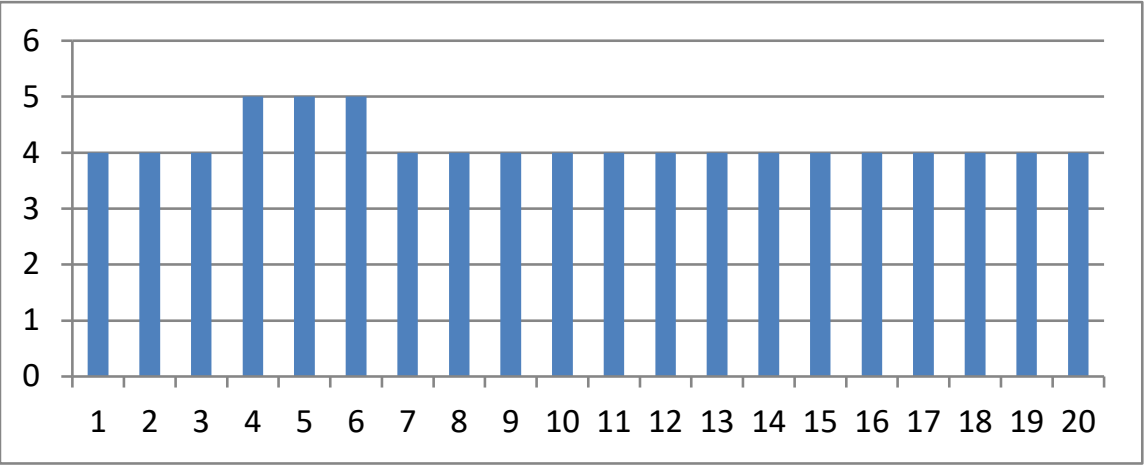

Berdasarkan penilaian hasil ahli pembelajaran terhadap lembar kerja siswa tunagrahita dengan menggunan strategi REACT di Home Schooling Primagama Malang sebagaimana dicantumkan, maka dapat dihitung prosentase tingkat pencapaian lembar kerja siswa sebagai berikut:

$$
\begin{aligned}
& \text { Prosentase }=\frac{\sum(\text { Jawaban } \times \text { Bobot tiap pilihan })}{n \times \text { Bobot tertinggi }} \times 100 \% \\
& \text { persentase }=\underline{20 \times 1} \times 100 \%=\frac{83}{100} \times 100 \%=83 \%
\end{aligned}
$$

Produk pengembangan yang diserahkan kepada uji coba lapangan dengan diwakili oleh satu kelas yakni kelas 4 dengan jumlah siswa sebanyak 5. Adapun data kuantitatif dari hasil penilaian uji coba lapangan sebanyak 5 orang adalah sebagaimana dipaparkan dalam berikut.

Berdasarkan hasil uji coba lapangan terhadap lembar kerja siswa tunagrahita dengan menggunanakan strategi REACT di Home Schooling Primagama Malang sebagaimana dicantumkan, maka dapat dihitung prosentase tingkat pencapaian lembar kerja siswa adalah sebagai berikut:

$$
\begin{gathered}
\text { Prosentase }=\sum \frac{(\text { Jawaban } \times \text { Bobot tiap pilihan })}{n \times \text { Bobot tertinggi }} \times 100 \% \\
\text { persentase }=\frac{425 \times 1}{20} \times 100 \%=85 \%
\end{gathered}
$$

Tabel nilai pre test dan post test yang didapat dari siswa kelas 4 pada saat uji coba lapangan adalah sebagai berikut:

Tabel C.1.

Hasil Uji Coba Lapangan pada Pre-Test

\begin{tabular}{cccc}
\hline Kriteria & $\mathbf{N}$ & $\mathbf{P}(\%)$ & Keterangan \\
\hline$<70$ & 3 & $60 \%$ & Tidak tuntas \\
\hline$>70$ & 2 & $40 \%$ & Tuntas \\
\hline
\end{tabular}

Pada tabel hasil pre test menunjukkan bahwa siswa yang kurang dari KKM adalah sebanyak 3, dan siswa yang mencapai KKM sebanyak 2 siswa dengan perbandingan 6:4, maka pembelajaran tematik di kelas 4 dikatakan masih belum tuntas. 


\section{MADRASAH}

Jurnal Pendidikan dan Pembelajaran Dasar

p ISSN: 1979-5599 | e ISSN: 2502-194X

Tabel C.2

Hasil Uji Coba Lapangan pada Post Test

\begin{tabular}{cccc}
\hline Kriteria & $\mathbf{N}$ & $\mathbf{P}(\%)$ & Keterangan \\
\hline$<70$ & 0 & - & - \\
\hline$>70$ & 5 & $100 \%$ & Tuntas \\
\hline
\end{tabular}

Pada tabel hasil post test menunjukkan bahwa siswa yang kurang dari KKM tidak ada, dan siswa yang mencapai KKM sebanyak 5 siswa dengan mencapai prosentase $100 \%$, maka pembelajaran tematik tunagrahita di kelas 4 dikatakan tuntas. Hal ini menunjukkan keefektifan dari pengembangan lembar kerja siswa tunagrahita dengan menggunan strategi REACT di Home Schooling Primagama Malang. Dari hasil post test sudah sangat membuktikan pentingnya pengembangan lembar kerja siswa tunagrahita ini, maka dari itu pengembangan lembar kerja siswa tunagrahita dengan menggunan strategi REACT di Home Schooling Primagama Malang penting untuk di terapkan bagi peserta didik di sekolah dasar. Data nilai pre test dan pots test tersebut selanjutnya melalui uji t paired samples t-test dengan bantuan computer SPSS 16. Hasil analisis uji adalah sebagai berikut:

Tabel C.4

Paired Sampel t-test

Paired Samples Statistics

\begin{tabular}{|ll|r|c|c|c|}
\hline & & Mean & $\mathrm{N}$ & Std. Deviation & Std. Error Mean \\
\hline Pair 1 & sebelum & 67.00 & 5 & 6.708 & 3.000 \\
& sesudah & 88.00 & 5 & 2.739 & 1.225 \\
\hline
\end{tabular}

Paired Samples Correlations

\begin{tabular}{|ll|c|c|c|}
\hline & $\mathrm{N}$ & $\begin{array}{c}\text { Correlatio } \\
\mathrm{n}\end{array}$ & Sig. \\
\hline Pair 1 & $\begin{array}{l}\text { sebelum \& } \\
\text { sesudah }\end{array}$ & 5 & .272 & .658 \\
\hline
\end{tabular}

Paired Samples Test

\begin{tabular}{|c|c|c|c|c|c|c|c|c|}
\hline & \multicolumn{5}{|c|}{ Paired Differences } & \multirow[b]{3}{*}{$\mathrm{T}$} & \multirow[b]{3}{*}{$\mathrm{df}$} & \multirow{3}{*}{$\begin{array}{l}\text { Sig. (2- } \\
\text { tailed) }\end{array}$} \\
\hline & \multirow[b]{2}{*}{ Mean } & \multirow{2}{*}{$\begin{array}{c}\text { Std. } \\
\text { Devia } \\
\text { tion }\end{array}$} & \multirow{2}{*}{$\begin{array}{l}\text { Std. } \\
\text { Error } \\
\text { Mean }\end{array}$} & \multicolumn{2}{|c|}{\begin{tabular}{|c|}
$95 \%$ \\
Confidence \\
Interval of the \\
Difference
\end{tabular}} & & & \\
\hline & & & & Lower & Upper & & & \\
\hline $\begin{array}{ll}\text { Pair } & \text { sebelum - } \\
1 & \text { sesudah }\end{array}$ & -21.000 & 6.519 & 2.915 & -29.095 & -12.905 & -7.203 & 4 & .002 \\
\hline
\end{tabular}


Dalam mengambil keputusan, dapat dilihat dari sig ( 2 tailed), apabila sig < 0,05 maka Ho ditolak dan Ha diterima. Hal ini berarti bahwa hasil belajar sesudah menggunakan lembar kerja siswa tunagrahita dengan menggunan strategi REACT di Home Schooling Primagama Malang lebih baik dari pada sebelumnya. Hal ini bisa dilihat dari data sig 0,02 yang diperoleh dari hasil uji t-tes yang menunjukkan bahwa ada perbedaan yang signifikan antara hasil belajar siswa sesudah menggunakan lembar kerja siswa tunagrahita dengan menggunan strategi REACT di Home Schooling Primagama Malang dibandingkan dengan sebelum menggunakan produk pengembangan.

\section{KESIMPULAN}

Berdasarkan proses pengembangan dan hasil uji coba terakhir terhadap lembar kerja siswa tunagrahita dengan menggunakan strategi REACT di Home Schooling Primagama Malang ini dipaparkan sebagai berikut:

1. Pengembangan ini menghasilkan produk berupa lembar kerja siswa tunagrahita dengan menggunan strategi REACT di Home Schooling Primagama Malang untuk siswa dengan spesifikasi format buku A4 dengan total 85 halaman.

2. Hasil uji coba lembar kerja siswa tunagrahita dengan menggunakan strategi REACT di Home Schooling Primagama Malang memiliki tingkat keefektifan dan kemenarikan yang tinggi berdasarkan hasil tanggapan dan penilaian guru dan uji coba lapangan yakni siswa kelas 4 Home Schooling Primagama Malang
a. Tanggapan penilaian ahli isi terhadap lembar kerja siswa tunagrahita dengan menggunakan strategi REACT adalah 86 \% dengan kualifikasi sangat baik
b. Tanggapan penilaian ahli desain pembelajaran terhadap lembar kerja siswa tunagrahita dengan menggunakan strategi REACT adalah 86\% dengan kualifikasi sangat baik.
c. Tanggapan penilaian ahli pembelajaran terhadap lembar kerja siswa tunagrahita dengan menggunakan strategi REACT adalah 83 \% dengan kualifikasi baik.
d. Tanggapan penilaian Uji coba lapangan terhadap lembar kerja siswa tunagrahita dengan menggunakan strategi REACT adalah 85 \% dengan kualifikasi sangat baik.

3. Perolehan hasil belajar berdasarkan uji coba lapangan yang diukur menggunakan ters pencapaian hasil belajar yaitu dengan merujuk Sign (2-tailed) sebesar 0,02, maka ada perbedaan yang signifikan antara rata-rata skor tes awal (pre-test) dengan tes akhir (post-test) setelah menggunakan lembar kerja siswa hasil pengembangan.

Dengan demikian, lembar kerja siswa tunagrahita dengan menggunakan strategi REACT bagi siswa kelas 4 ini dapat dikatakan mempunyai kualitas baik. Hal ini dikarenakan penggunaan lembar kerja siswa ini dapat membantu meningkatkan keefektifan dan kemenarikan pembelajaran dan membantu mempermudah siswa belajar serta membantu meningkatkan perolehan belajar siswa dalam proses pembelajaran tematik.

\section{REFERENSI}

Apriyanto, Nunung. 2010. Seluk Beluk Tunagrahita dan Strategi Pembelajarannya. Yogyakarta: Javalitera. 


\section{MADRASAH}

Jurnal Pendidikan dan Pembelajaran Dasar

p ISSN: 1979-5599 | e ISSN: 2502-194X

P a g e | 139

Crowford. 2001. Teaching Contextually Research, Rationale, and Technique for Improving Student Motivation and Achievement in Mathematics and Science. Texas: CCI Publishing

Delphie. Bandi. 2006. Pembelajaran Anak Berkebutuhan Khusus. Bandung: Rafika Aditama.

Endang Rocyadi, dan Zaenal Abidin. 2005. Pengembangan Program Pembelajaran Bagi Anak Tunagrahita. Jakarta: Depennas.

Hidayat. 2010. Pembelajaran Kontekstual dengan REACT dalam Upaya Pengembangan Kemampuan Pemecahan Masalah, Berfikir Kritis, dan Berfikir Kreatif Matematis Mahasiswa Bidang Bisnis.(Disertasi UPI).

Hobti. 2010. Metodologi Penelitian Pengembangan. Mangli: Pena

Isjoni. 2007. Cooperative Learning (Efektivitas Pembelajaran Kelompok). Bandung: Alfabeta

Mathen. 2010. Pembelajaran Melalui Pendekatan REACT Meningkatkan Kemampuan Matematis Siswa SMP. Jurnal Penelitian Pendidikan Vol 11, No.2: UPI Bandung

Abidin, Muh. Bahan Ajar dan Pengembangan Bahan Ajar. Meetabied. Wordpress.com.

Muljono. 1994. Pendidikan Luar Biasa Umum. Jakarta: Departemen Pendidikan dan Kebudayaan Direktorat Jenderal Pendidikan Tinggi.

Murni, Wahid, dan Nur Ali. 2008. Penelitian Tindakan Kelas Pendidikan Agama dan Umum Dari Teori Menuju Disertai Contoh Hasil Peneliti. Malang: UM Press.

Pannen. 2001. Penulisan Bahan Ajar. Jakarta: Pusat antar Universitas.

Prastowo, Andi. 2011. Bahan Ajar Inovatif. Jogjakarta: Diva Press

Rohati. 2011. Pengembangan Bahan Ajar Materi Bangun Ruang dengan Menggunakan Strategi Relating, Experiencing, Applying, Cooperating, Transferring (REAST) di Sekolah Menengah Pertama. Edumatica

Sudjana. 2002. Desain dan Analisis Eksperimen. Bandung: PT. Tarsito

Sugiyono. 2012. Metode Penelitian Pendidikan: Pendekatan Kuantitatif, Kualitatif, \& RND. Bandung: Alfabeta

Suhena. 2009. Pengaruh Strategi REACT dalam pembelajaran Matematika Terhadap Peningkatan Kemampuan Pemahaman, Penalaran dan Komunikasi Matematis Siswa. [Disertasi] UPI: Tidak Diterbitkan

Sukandi. 2003. Belajar Aktif dan Terpadu. Surabaya: Duta Graha Pustaka.

Trianto. 2011. Desain Pengembangan Pembelajaran Tematik Bagi Anak Usia Dini TK/RA \& Anak Usia Kelas Awal SD/MI. Jakarta: Kencana. 